\title{
Lymphocyte Blastogenesis in Hairless Dogs Following Stimulation by Various Mitogens
}

\author{
Nobuo KOIZUMI and Katsuhiro FUKUTA \\ National Institute of Animal Health, 3-1-1 Kannondai, \\ Tsukuba-shi, Ibaraki 305, Japan
}

(Received 25 December 1991/Accepted 15 May 1992)

\begin{abstract}
Lymphocyte blastogenesis in hairless descendants of Mexican hairless dogs was examined using the following mitogens: phytohemagglutinin (PHA-M), Concanavalin A (Con A), lipopolysaccharide (LPS) and pokeweed mitogen (PWM). Blastogenetic responses to these mitogens were measured by glucose consumption test (GCT) and compared with those of haired beagle dogs. The response to PHA$M$ was significantly less in the hairless dogs than in the beagles. No significant differences in the responses to Con A, PWM and LPS were recognized. These results indicated $\mathrm{T}$-cell dysfunction in the hairless dogs, coinciding with our previous work showing reduction of the delayed-type hypersensitivity reaction and early degeneration of the thymus. - KEY WORDS : hairless dog, lymphocyte blastogenesis, T-cell dysfunction
\end{abstract}

Mexican hairless dogs are native to Mexico and have almost no hair. Their hairlessness is considered to be controlled by an autosomal dominant gene [5]. In our laboratory, hairless descendants of a Mexican hairless dog have been maintained by mating with beagles. In addition to hairlessness, the hairless dogs show thymus atrophy soon after birth [4], reduced antibody production and delayed-type hypersensitivity reactions [6]. In the present study, the blastogenetic responses of lymphocytes in the hairless dogs were examined by using mitogens including phytohemagglutinin$\mathrm{M}$ (PHA-M), Concanavalin A (Con A), lipopolysaccharide (LPS) and pokeweed mitogen (PWM).

Seven hairless dogs of both sexes (1.3-4.5 years old) were used in the present study. They included $F_{1}$ hybrid (beagle $\times$ Mexican hairless) and backcross $F_{2}$ (beagle $\times F_{1}$ hairless) dogs. Five beagles of similar age (1.3-5.5 years old) were also used as control haired dogs. All dogs were clinically healthy at the time of the study. Five ml of blood was collected through the cephalic vein of each dog and heparinized. Part of each sample was subjectcd to routine hematological examinations (Table 1). The remaining blood was laid on Histopaque (Sigma), centrifuged at $400 \mathrm{~g}$ for $30 \mathrm{~min}$, and then the lymphocyte fraction was separated. The lymphocyes were washed three times with phosphate buffered saline (PBS), resuspended at a concentration of $10^{\circ}$ cells $/ \mathrm{ml}$ in RPMI 1640 medium supplemented with $10 \%$ fetal calf serum, and cultured in $5 \% \mathrm{CO}_{2}, 95 \%$ air at $37^{\circ} \mathrm{C}$ for $72 \mathrm{hr}$. The mitogens added to stimulate the medium included PHA-M $(5,10,20,40 \mu \mathrm{g} /$ $\mathrm{ml}$, Con A (5, 10, $20 \mu \mathrm{g} / \mathrm{ml})$, LPS $(5,10,20,40$ $\mu \mathrm{g} / \mathrm{ml})$ and PWM $(0.05,0.1,0.2 \%)$; control medium was prepared without any mitogen.

Blastogenetic response was evaluated by the glucose consumption test (GCT) $[1,2,7,11$, 12]. After culture, the glucose concentration in the medium was measured by a TOECHO III (Kodama Co., Japan), and the stimulation ratio (SR) was calculated by the following 
Table 1. Hematological values in hairless and beagle dogs

\begin{tabular}{|c|c|c|c|}
\hline & $\begin{array}{l}\text { Hairless dogs } \\
\quad(n=7)\end{array}$ & \multicolumn{2}{|c|}{$\begin{array}{c}\text { Beagles } \\
(n=5)\end{array}$} \\
\hline $\begin{array}{c}\mathrm{RBC} \\
\left(\times 10^{6} / \mathrm{mm}^{3}\right)\end{array}$ & $755.7 \pm 56.5^{*}$ & \multicolumn{2}{|c|}{$780.8 \pm 112.7$} \\
\hline $\begin{array}{l}\mathrm{PCV} \\
(\%)\end{array}$ & $52.0 \pm 3.3$ & $52.2 \pm$ & 5.5 \\
\hline $\begin{array}{c}\text { WBC } \\
\left(\times 10^{3} / \mathrm{mm}^{3}\right)\end{array}$ & $13.2 \pm 2.4$ & $11.2 \pm$ & 2.0 \\
\hline \multicolumn{4}{|l|}{ Differential } \\
\hline Neutrophils $(\%)$ & $62.6 \pm 4.6$ & $59.4 \pm$ & 7.2 \\
\hline Eosinophils $(\%)$ & $7.1 \pm 2.0$ & $4.4 \pm$ & 1.1 \\
\hline Basophils $(\%)$ & $0.4 \pm 0.5$ & $0.2 \pm$ & 0.4 \\
\hline Lymphocytes $(\%)$ & $25.9 \pm 4.3$ & $31.2 \pm$ & 4.9 \\
\hline Monocytes $(\%)$ & $4.0 \pm 1.4$ & $4.8 \pm$ & 2.3 \\
\hline
\end{tabular}
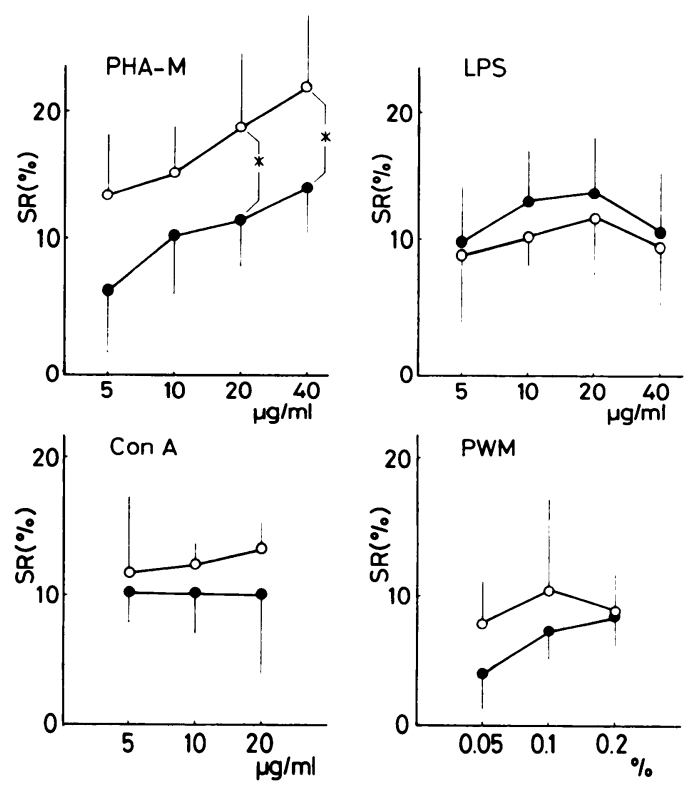

Fig. 1. Blastogenetic responses of lymphocytes in hairless and beagle dogs to PHA-M, LPS, Con $A$ and PWM. solid circles : hairless dog open circles : beagle dog vertical lines: standard deviations $*$ : significant difference $(\mathrm{P}$ $<0.05)$

formula.

$$
\mathrm{SR}(\%)=(\mathrm{C}-\mathrm{S}) / \mathrm{C} \times 100
$$

$\mathrm{C}$ : glucose concentration in control medium $(\mathrm{mg} / \mathrm{dl})$

$\mathrm{S}$ : glucose concentration in stimulated medium $(\mathrm{mg} / \mathrm{dl})$

The results of hematological examinations (Table 1) showed no significant differences in hematological values between the hairless and beagle dogs. Kimura et al. [8] reported that the red blood cell count, hemoglobin concentration and packed cell volume in hairless dogs (aged 1-2 years old) were higher than those in beagles (aged 1-6 years old). Considering the influence of aging [3], however, the hematological values were probably not significantly different between the hairless and beagle dogs.

The SR values for each mitogen are shown in Fig. 1. The blastogenetic response of lymphocytes to PHA-M was significantly lower in the hairless dogs than in the beagles $(P<0.05)$. Although the responses to Con A and PWM were slightly lower in the hairless dogs and that to LPS was higher, no significant differences were recognized in the SR values for these mitogens.

PHA-M and Con A are generally used as T-cell mitogens [10], and LPS and PWM as Bcell mitogens $[13,14]$. Kurakowka et al. [9] reported that $\mathrm{PHA}-\mathrm{P}$ stimulated both $\mathrm{T}$-and B-cells in dogs, while Con A affected only Tcells. In the present study of hairless dogs, the blastogenetic response of lymphocytes to PHA-M was significantly decreased but that to Con A was not. No signs of B-cell reduction were exhibited by other mitogens. Furthermore, the relative population of $\mathrm{T}$-cells in the peripheral blood of hairless pups was decreased by half in haired littermates (unpublished data). These findings indicate that the reduced response to PHA-M seems to depend on a decrease in $\mathrm{T}$-cell function or the $\mathrm{T}$-cell population in hairless dogs.

In conclusion, the decreased lymphocyte blastogenesis in the hairless dog was a result of T-cell dysfunction, coincidng with our previous findings on the early degeneration of the thymus [4] and the reduction of delayedtype hypersensitivity reactions and antibody production [6].

We wish to thank Mr. K. Watanabe and Mr. Y. Yoshioka for their kind care of the hairless dogs. We also thank Dr. Y. Maruyama and Mr. K. Imamura for their assistance in preparing samples. This work was supported in part by 
Special Coordination Funds for Promoting Science and Technology from the Science and Technology Agency of the Japanese Government.

\section{References}

[1] DeCock, W., DeCree, J., VanWauwe, J., and Verhaegen, H. (1980). J. Immunol Methods, 33, 127131

[2] Ejima, H., Murata, A., Nakanishi, A., Hara, Y., and Tagawa, M. (1988). Jpn. J. Vet. Sci, 50, 840-841.

[3] Fukuda, S., Kawashima, N., Iida, H., Aoki, J., and Tokita, K. (1989). Jpn. J. Vet. Sci, 51, 636-641.

[4] Fukuta, K., Koizumi, N., Imamura, K., Goto, N., and Hamada, H. (1991). Exp Anim, 40, 69-76.

[5] Goto, N., Imamura, K., Miura, Y., Ogawa, T., and Hamada, H. (1987). Exp, Anim, 36, 87-90.

[6] Hirota, Koizumi, N., Matsubara, Y., Imamura, K., and
Fukuta, K. (1990). Jpn. J. Vet. Sci, 52, 1117-1121.

[7] Ishikawa, H. and Shirahata, T. (1986). Jpn. J. Vet. Sci, 48, 111-115.

[8] Kimura, T., Ohshima, S., and Iida, K. (1990). Exp Anim, 39, 417-420.

[9] Krakowka, S. and Ringler, S. S. (1986). Vet. Immanol Immunopathol, 11, 281-289.

[10] Kristensen, B., Kristensen, F., Vandevelde, M., Higgins, R. J., and DeWeck, A. L. (1982). Vet. Immunol Immunopathol, 3, 439-448.

[11] MacHaffie, R. A. and Wang, C. H. (1967). Blood, 29, 640-646.

[12] Nakanishl, A., Aimi, K., Ejima, H., and Kurokawa, K. (1986). Jpn. J. Vet. Sci, 48, 53-60.

[13] Peavy, D. L., Adler, W. H., Shands, J. W., and Smith, R. T. (1974). Cell Immunol, 11, 86-98.

[14] Rosenberg, S. A. and Lipsky, P. E. (1979). J. Immunol, 122, 926-931.

\section{ヘアレス犬リンパ球の各種マイトジェン \\ による芽球化反応 \\ 小泉伸夫・福田勝洋}

\section{農林水産省家畜衛生試験場研究第一部実験動物研究室}

\footnotetext{
メキシカン・ヘアレスドッグに由来するへアレス犬の

リンパ球を末梢血より分離, 培養し, 各種マイトジェン による芽球化反応をブドウ糖消費試験によって測定し た。ヘアレス犬リンパ球の PHA-Mによる芽球化能は, ビーグル犬に比べ有意に低下した。ConA, PWM およ
}

び LPS ではへアレス犬とビーグル犬との有意差はなか った。以上の結果から，ヘアレス犬ではT細胞の機能低 下あるいは細胞数の減少が示唆され，ヘアレス犬でみら れる胸腺の退行性変化や遅延型過敏症反応の低下と対応 することが認められた。 